\title{
Correction to: An automated system analysis and design tool for spacecrafts
}

\author{
Manfred Ehresmann $^{1}$ (D) $\cdot$ Georg Herdrich ${ }^{1} \cdot$ Stefanos Fasoulas $^{1}$
}

Published online: 29 August 2021

(c) CEAS 2021

\section{Correction to: CEAS Space Journal https://doi.org/10.1007/s12567-021-00383-3}

Original version contains journal name in title which is corrected through this correction.

Original article has been corrected.

Open Access This article is licensed under a Creative Commons Attribution 4.0 International License, which permits use, sharing, adaptation, distribution and reproduction in any medium or format, as long as you give appropriate credit to the original author(s) and the source, provide a link to the Creative Commons licence, and indicate if changes were made. The images or other third party material in this article are included in the article's Creative Commons licence, unless indicated otherwise in a credit line to the material. If material is not included in the article's Creative Commons licence and your intended use is not permitted by statutory regulation or exceeds the permitted use, you will need to obtain permission directly from the copyright holder. To view a copy of this licence, visit http://creativecommons.org/licenses/by/4.0/.

Publisher's Note Springer Nature remains neutral with regard to jurisdictional claims in published maps and institutional affiliations.

The original article can be found online at https://doi.org/10.1007/ s12567-021-00383-3.

Manfred Ehresmann

ehresmann@irs.uni-stuttgart.de

Georg Herdrich

herdrich@irs.uni-stuttgart.de

Stefanos Fasoulas

fasoulas@irs.uni-stuttgart.de

1 Institute of Space Systems University of Stuttgart, Pfaffenwaldring 29, 70569 Stuttgart, Germany 